\title{
Assessment of Chemical, Rheological and Sensory Properties of Fermented Maize-Cardaba Banana Complementary Food
}

\author{
Helen Nwakego Ayo-Omogie*, Regina Ogunsakin \\ Food Science and Technology Department, Federal University of Technology, Akure, Nigeria \\ Email: "helenatum2002@yahoo.com
}

Received May $6^{\text {th }}, 2013$; revised June $6^{\text {th }}, 2013$; accepted June $14^{\text {th }}, 2013$

Copyright (C) 2013 Helen Nwakego Ayo-Omogie, Regina Ogunsakin. This is an open access article distributed under the Creative Commons Attribution License, which permits unrestricted use, distribution, and reproduction in any medium, provided the original work is properly cited.

\begin{abstract}
Traditional processing of fermented maize ("ogi"), a popular weaning food in the West African sub-region, results in considerable nutrient losses. Several attempts at improving its nutritional and sensory properties have focused on fortification with plant and animal products. Banana flour, rich in micronutrients and vitamins, could increase the micronutrient and vitamin contents of ogi. This study aimed at evaluating the physicochemical properties and sensory attributes of ogi as influenced by banana flour supplementation. Fermented maize flour was substituted with ripe Cardaba banana flour at levels of $10 \%-50 \%$ and the flour mixes subjected to chemical, rheological and sensory evaluation. Crude protein decreased from $1.59 \%$ to $1.43 \%$ as banana flour substitution increased, while ash, total sugar (3.64\% to $4.97 \%$ ), carbohydrate and acidity increased. However, diastatic activity, crude fibre and fat were not significantly $(\mathrm{p} \leq 0.05)$ affected. Results of functional properties revealed the following: $86.49-83.63 \mathrm{~g} / \mathrm{ml}, 0.41-0.44 \mathrm{~g} / \mathrm{cm}^{3}, 6.44-7.46 \mathrm{~g} / \mathrm{ml}$, $3.30-4.50 \mathrm{~g} / \mathrm{ml}$, and $10.40-10.80 \mathrm{~g} / \mathrm{ml}$ for water absorption capacity, bulk density, gel consistency, syneresis and swelling capacity, respectively. Significant $(\mathrm{p} \leq 0.05)$ variations were observed in the pasting viscosities of the flours. The 50:50 maize-banana flour mix was the most preferred in terms of aroma, taste, colour and general acceptability. The addition of Cardaba banana flour to ogi may enhance its micronutrient content as evidenced by increased ash content, sensory, functional and pasting properties, thereby making it a potential substitute for complementary feeding of infants.
\end{abstract}

Keywords: Cardaba Banana; Complementary Food; Fermented Maize; Micronutrients; Ogi; Rheological; Sensory; Substitution

\section{Introduction}

Ogi is an acid-fermented cereal gruel or porridge made from maize, sorghum, or millet; the choice of cereal depending on preference and ethnicity. It is popular in Nigeria and in most West African countries, where it is mainly used for complementary feeding of infants; although it is also consumed by adults. Ogi porridges are smooth in texture, perhaps similar to hot blancmange and a sour taste reminiscent of that of yoghurt [1]. During fermentation, enzymes elaborated by the fermenting microorganisms break down many complex substances such as starch, oligosaccharides, protein and phytic acid complexes thus increasing the quantities and qualities of easily-digestible nutrients in foods. This feature is a ma-

"Corresponding author. jor benefit to the consumers of ogi, who are majorly infants, children and convalescent adults with weak digestive systems. Due to poor state of technological advancement in traditional food processing, the processing methods of ogi are usually susceptible to problems of food loss, labour-intensive operations and possible poor quality end-products. Hence, several attempts have been made to improve the nutritional status of ogi by fortification with protein-rich substrates including soya beans, groundnuts, melon seeds and cowpea. However, nutritional improvements of these fermented cereal gruels with protein-rich substrates lowered their pasting viscosities and sometimes affected their sensory attributes adversely. These factors are likely to influence consumer acceptability [2]. Much more recently, fruits such as ripe dessert banana flour [3], baobab [4] and pawpaw [5] 
among others, have been incorporated into ogi for quality improvement. These fruits are able to significantly improve the sensory properties and increase ash, ascorbic acid, sugars and mineral contents of ogi since fruits are rich in minerals, vitamins and sugars.

Cardaba banana (Musa ABB) is an under-utilized cooking banana variety which is though available year round in Southern Nigeria, is highly restricted in utilization to production of flour and fried chips, thereby predisposing it to rapid post harvest spoilage contributed by its physiological metabolic activities and high moisture content. It is relatively cheaper as compared to dessert bananas and plantains and has been reported to be rich in minerals, ash and ascorbic acid [6]. There are extensive reports on the processing and utilization of dessert banana and its flour for various food industrial purposes in Nigeria; therefore the need arises to fully harness the potentials in cooking bananas which are highly available, relatively cheaper and much more hardy. Hence, this study has investigated the effect of Cardaba banana supplementation on the physiochemical and sensory attributes of ogi.

\section{Materials and Methods}

\subsection{Materials}

Quality Protein Maize (QPM) was obtained from IAR \& T, Ibadan, Nigeria while green mature Cardaba banana fruits (Musa ABB) were obtained from the Teaching and Research Farm of the Federal University of Technology Akure, Nigeria. The bananas were ripened naturally to stage 3 ripeness (more yellow than green). This was selected because after this stage of ripening (from stages 4 - 7), flour from Cardaba banana becomes increasingly discoloured and dark-brown [6].

\subsection{Preparation and Blending of Ogi and Banana Flours}

Fermented maize (ogi) was prepared using the traditional method described by Adeyemi and Soluade [5] which involved steeping of clean maize grains for $24 \mathrm{~h}$, wet milling, wet sieving, decanting, drying at $50^{\circ} \mathrm{C}$ for $24 \mathrm{~h}$ in a cabinet dryer, cooling to ambient temperature, milling in an attrition mill and packaging in polythene bags. Cardaba banana flour was produced by washing of the fingers, peeling, slicing into $10 \mathrm{~mm}$ chips, soaking in $0.05 \%$ sodium metabisulphite solution for $5 \mathrm{~min}$ and dried using a Gallenkamp hot air oven (Model 320; Gallenkamp, England) at $50^{\circ} \mathrm{C}$ for $24 \mathrm{~h}$. The dried chips were milled using a hammer mill (Armfield), sieved to pass through a $250 \mu \mathrm{m}$ sieve and packaged in polythene bags. Blending of the flours was done by supplementing ogi flour with Cardaba banana flour at levels ranging from $10 \%-50 \%$.

\subsection{Analyses}

\subsubsection{Determination of Chemical Composition of the Mixes}

Triplicate samples were analyzed for proximate composition, total sugars, diastatic activity and titratable acidity (expressed as percent lactic acid) using standard official methods [7].

\subsubsection{Evaluation of Functional and Pasting Properties of the Flours and Their Blends}

The samples were evaluated for water absorption capacity [8], bulk density [9] and pasting viscosity using Rapid Visco Analyzer (Model: RVA-4, Newport Scientific Pty. Ltd., Sydney, Australia) [10]. Syneresis was determined by preparing a gel from each mix at $16 \%$ concentration (dry basis) in a total weight of $600 \mathrm{~g}$. This was achieved by heating the slurry obtained after addition of water, with constant stirring to form a thick paste, which was then poured into size cans. The gel obtained (about $5 \mathrm{~cm}$ in diameter and $2 \mathrm{~cm}$ in height) was placed on a sheet of filter paper in a place free from draft and at a uniform temperature. After an interval of $1 \mathrm{~h}$, distance travelled by the water of syneresis along the filter was determined [3]. Consistency was determined by preparing a slurry of $10 \%$ total solids (dry basis), one-third of the water was mixed with the flour, while the remaining two-thirds was boiled, poured into the slurry, cooked for $2-3 \mathrm{~min}$ and later cooled to $50^{\circ} \mathrm{C}$. The cooled paste was then poured into Adam's consistometer cup, which was then raised, and the extent of flow was read after $30 \mathrm{~s}$ [3]. Swelling capacity was determined by adding $150 \mathrm{ml}$ of cold water into $25 \mathrm{~g}$ of each sample in a $210 \mathrm{ml}$ measuring cylinder, allowed to stand for $4 \mathrm{~h}$ before observing the level of swelling and thereafter calculated as [11]:

$$
\begin{aligned}
& \text { Swelling capacity } \\
& =\frac{\text { volume after soaking }- \text { volume before soaking }}{\text { Weight of sample }}
\end{aligned}
$$

\subsubsection{Sensory Evaluation}

Gruel was prepared from each of the samples by boiling $10 \%(\mathrm{w} / \mathrm{v})$ slurry for $15 \mathrm{~min}$ and assessed for colour, aroma, taste, mouth feel and overall acceptability by a team of 20 panelists familiar with ogi gruel. A Nine (9) point hedonic scale, where 9 represented "like extremely" and 1 "dislike extremely", was employed. Each treatment was evaluated three times by each panelist. Samples were served immediately after preparation. Each judge was presented with a glass of water after each testing session to rinse his mouth so as to prevent a carryover effect.

\subsubsection{Statistical Analysis}

Triplicate results were subjected to statistical analysis 
using Statistical Package for Social Scientists (SPSS) software version 15.0. The mean values and standard deviation were calculated while Analysis of Variance (ANOVA) was performed and means separated by the Duncan's Multiple Range Test at $\mathrm{p} \leq 0.05$.

\section{Results and Discussion}

\subsection{Chemical Composition of the Mixes}

Variations in the chemical composition of ogi as affected by banana flour addition are presented in Table 1 . The low moisture content of the mixes which ranged from $10.56 \%$ to $10.31 \%$ for $10 \%$ and $50 \%$ substitution levels respectively, signify good storability of the products because milled food products with moisture content less than $13 \%$ are stable from moisture dependent deterioration [12]. Protein content decreased from $1.63 \%$ in the control (100\% fermented maize flour) to 1.43 at $50 \%$ banana substitution. Similar decreases have been reported in maize flour substituted with banana flours and pawpaw $[3,5]$. This may be due to dilution, since banana is a poor source of protein. Hence, complementary diets formulated from maize-banana blends need to be supplemented with animal proteins such as milk or crayfish as is being practiced in traditional Nigerian setting. Fat content also reduced on banana flour addition. This is expected because banana has low fat content and contributes very little of lipid material to foods [13]. There were significant improvements in the ash contents of the blends from $1.34 \%$ to $1.46 \%$ as substitution increased. This increase could be due to the minerals in banana since Cardaba banana has been shown to be a good source of minerals, particularly potassium, magnesium and phosphorus [6].

There was, however, no significant difference in the crude fibre content of the ogi flour. Carbohydrate and total sugar of the blends which ranged from $85.16 \%$ to $85.34 \%$ and $3.64 \%$ to $4.97 \%$ respectively, increased as banana substitution levels increased. This may be due to the high sugar and starch content of banana [14]. Titratable acidity of the samples increased significantly $(\mathrm{p} \leq$ 0.05 ) from 0.12 to 0.24 lactic acid (Table 1). This indicates that the banana flour significantly contributed to the acidity of the mixes, a feature which is beneficial for gastrointestinal health of ogi consumers. Diastatic activity which was low did not show any significant $(\mathrm{p} \leq 0.05)$ difference on addition of banana flour. Although diastatic activity is important in baking, it is however relevant in this study because high diastatic activity imparts heaviness and stickiness to the fermenting dough, thereby making the resultant loaves dense, of low volume and poor waxy texture [15]. Therefore the low diastatic activity recorded in this study is an indication that the resulting weaning food will not be heavy, sticky or have a poor waxy texture which may make it unacceptable to consumers. It also shows the suitability of these flour mixes for baking purposes.

\subsection{Functional Properties of the Flours and Mixes}

Results of functional properties of fermented maize flour and the blends are presented in Table 2. Water absorption capacity of banana flour $(90.44 \mathrm{~g} / \mathrm{ml})$ was lower than that of fermented maize flour $(93.63 \mathrm{~g} / \mathrm{ml})$. On addition of $10 \%$ banana flour to fermented maize flour, water

Table 1. Chemical composition of fermented maize and maize-Cardaba banana flour blends.

\begin{tabular}{|c|c|c|c|c|c|c|c|}
\hline \multirow[b]{2}{*}{ Composition } & \multicolumn{6}{|c|}{ Level of substitution } & \multirow[b]{2}{*}{$100 \%$} \\
\hline & $0 \%$ & $10 \%$ & $20 \%$ & $30 \%$ & $40 \%$ & $50 \%$ & \\
\hline Crude protein $(\%)$ & $1.63^{\mathrm{a}}$ & $1.59^{\mathrm{b}}$ & $1.53^{\mathrm{c}}$ & $1.52^{\mathrm{c}}$ & $1.47^{\mathrm{d}}$ & $1.43^{\mathrm{e}}$ & $1.26^{\mathrm{f}}$ \\
\hline Fat $(\%)$ & $0.38^{\mathrm{a}}$ & $0.31^{\mathrm{b}}$ & $0.36^{\mathrm{ab}}$ & $0.36^{\mathrm{ab}}$ & $0.35^{\mathrm{ab}}$ & $0.34^{\mathrm{ab}}$ & $0.29^{\mathrm{c}}$ \\
\hline Ash (\%) & $1.27^{\mathrm{f}}$ & $1.34^{\mathrm{e}}$ & $1.38^{\mathrm{d}}$ & $1.39^{\mathrm{d}}$ & $1.42^{\mathrm{c}}$ & $1.46^{\mathrm{b}}$ & $2.95^{\mathrm{a}}$ \\
\hline Crude Fibre (\%) & $1.15^{\mathrm{a}}$ & $1.04^{\mathrm{c}}$ & $1.10^{\mathrm{b}}$ & $1.13^{\mathrm{ab}}$ & $1.12^{\mathrm{ab}}$ & $1.12^{\mathrm{ab}}$ & $1.05^{\mathrm{c}}$ \\
\hline Carbohydrate (\%) & $84.94^{\mathrm{e}}$ & $85.16^{\mathrm{cd}}$ & $85.18^{c}$ & $85.19^{c}$ & $85.28^{\mathrm{b}}$ & $85.34^{\mathrm{a}}$ & $84.07^{\mathrm{f}}$ \\
\hline Total sugar (g/100g) & $3.64^{\mathrm{g}}$ & $4.34^{\mathrm{f}}$ & $4.84^{\mathrm{e}}$ & $4.97^{\mathrm{d}}$ & $5.00^{\mathrm{bc}}$ & $5.06^{\mathrm{a}}$ & $5.02^{\mathrm{ab}}$ \\
\hline Total Titratable Acid (\% lactic acid) & $0.12^{\mathrm{de}}$ & $0.14^{\mathrm{d}}$ & $0.15^{\mathrm{cd}}$ & $0.17^{\mathrm{c}}$ & $0.22^{\mathrm{ab}}$ & $0.24^{\mathrm{a}}$ & $0.17^{\mathrm{c}}$ \\
\hline
\end{tabular}

Each value is a mean of triplicate determination. Values in the same row with same letters are not significantly different $(\mathrm{p}<0.05) .0 \%=100 \%$ fermented maize flour, $10 \%=90 \%$ fermented maize flour $+10 \%$ Cardaba banana; $20 \%=80 \%$ fermented maize flour $+20 \%$ Cardaba banana; $30 \%=70 \%$ fermented maize flour $+30 \%$ Cardaba banana; $40 \%=60 \%$ fermented maize flour $+40 \%$ Cardaba banana; $50 \%=50 \%$ fermented maize flour $+50 \%$ Cardaba banana; and $100 \%=$ $100 \%$ Cardaba banana flour. 
Table 2. Functional properties of maize flour, Cardaba banana flour and the blends.

\begin{tabular}{|c|c|c|c|c|c|}
\hline $\begin{array}{c}\text { Level of substitution with Cardaba banana } \\
\text { (\%) }\end{array}$ & $\begin{array}{l}\text { Water absorption capacity } \\
(\mathrm{g} / \mathrm{ml})\end{array}$ & $\begin{array}{l}\text { Bulk density } \\
\left(\mathrm{g} / \mathrm{cm}^{3}\right)\end{array}$ & $\begin{array}{l}\text { Consistency } \\
(\mathrm{g} / \mathrm{ml})\end{array}$ & Syneresis $(\mathrm{g} / \mathrm{ml})$ & $\begin{array}{l}\text { Swelling capacity } \\
(\mathrm{g} / \mathrm{ml})\end{array}$ \\
\hline 0 & $93.63^{\mathrm{a}}$ & $0.43^{\mathrm{ab}}$ & $7.28^{\mathrm{b}}$ & $3.70^{\mathrm{c}}$ & $10.80^{\mathrm{a}}$ \\
\hline 10 & $86.49^{\mathrm{g}}$ & $0.42^{\mathrm{bc}}$ & $7.46^{\mathrm{a}}$ & $3.90^{\mathrm{c}}$ & $10.63^{b}$ \\
\hline 20 & $88.80^{\mathrm{d}}$ & $0.44^{\mathrm{a}}$ & $6.92^{\mathrm{d}}$ & $4.00^{\mathrm{b}}$ & $10.52^{\mathrm{c}}$ \\
\hline 30 & $88.60^{\mathrm{e}}$ & $0.43^{\mathrm{ab}}$ & $6.79^{\mathrm{d}}$ & $3.30^{\mathrm{e}}$ & $10.51^{\mathrm{c}}$ \\
\hline 40 & $89.19^{\mathrm{c}}$ & $0.42^{\mathrm{bc}}$ & $6.74^{\mathrm{d}}$ & $4.50^{\mathrm{a}}$ & $10.45^{\mathrm{d}}$ \\
\hline 50 & $87.49^{\mathrm{f}}$ & $0.41^{\mathrm{c}}$ & $6.44^{\mathrm{e}}$ & $3.70^{\mathrm{c}}$ & $10.40^{\mathrm{e}}$ \\
\hline 100 & $90.44^{\mathrm{b}}$ & $0.41^{\mathrm{c}}$ & $6.95^{\mathrm{d}}$ & $3.60^{\mathrm{d}}$ & $10.30^{\mathrm{f}}$ \\
\hline
\end{tabular}

Each value is a mean of triplicate determination. Values in the same row with same letters are not significantly different $(\mathrm{p}<0.05) .0 \%=100 \%$ fermented maize flour, $10 \%=90 \%$ fermented maize flour $+10 \%$ Cardaba banana; $20 \%=80 \%$ fermented maize flour $+20 \%$ Cardaba banana; $30 \%=70 \%$ fermented maize flour $+30 \%$ Cardaba banana; $40 \%=60 \%$ fermented maize flour $+40 \%$ Cardaba banana; $50 \%=50 \%$ fermented maize flour $+50 \%$ Cardaba banana; and $100 \%=$ $100 \%$ Cardaba banana flour.

absorption initially reduced to $86.49 \mathrm{~g} / \mathrm{ml}$ and increased at substitution levels of $20 \%-40 \%$ but finally reduced with $50 \%$ banana flour to $87.49 \mathrm{~g} / \mathrm{ml}$. This may be attributed to the coarse nature of banana flour since flours with bigger or coarse particle sizes have been reported to retain less water as compared to flours with smaller or finer particle size [16]. Secondly, the increase in the sugar content of ogi flour as banana flour substitution increased may also be responsible for the reduced water absorption. This is because sugars are known to inhibit the hydration of starch [17,18]. This reduction may, however, be an advantage since low water absorption capacity is desirable for formulation of low viscous, less bulky and more nutritious weaning foods [19].

Bulk density of the flours ranged from $0.41-0.44$ $\mathrm{g} / \mathrm{cm}^{3}$. Addition of Cardaba banana flour to ogi flour in most cases reduced its bulk density, although this reduction was not significant $(\mathrm{p} \leq 0.05)$ except at $50 \%$ substitution level. The reduction may be attributed to the high content of sugar of the banana [6]. Although high bulk density is important due to the packaging advantage it offers flour products [20], low bulk density could be an advantage in the formulation of baby foods where high nutrient density to low bulk is desired. This is because the lower the BD value, the higher the amount of flour particles that can stay together and thus increasing the energy content that could be derivable from such diets [21].

Consistency of the flours which ranged from 6.44 to $7.46 \mathrm{~g} / \mathrm{ml}$; initially increased at $10 \%$ banana flour inclusion from $7.28 \mathrm{~g} / \mathrm{ml}$ to $7.46 \mathrm{~g} / \mathrm{ml}$, but reduced thereafter to $6.44 \mathrm{~g} / \mathrm{ml}$ at $50 \%$ banana substitution. This is consistent with the report of Okezie et al. [3] in weaning food formulation using Cavendish banana and fermented maize flour. It also shows the relationship between the consistency and pasting viscosities of the flours which reduced in most cases in this study as Cardaba banana flour substitution increased. Syneresis however, generally increased with increasing banana substitution, except at the $40 \%$ substitution. This could be due to increase in sugar levels that retard gelatinization and swelling of starch [18]. Also water separation due to starch crystallization could occur during storage of the gels. As a result of this it could lead to hydrogen bond disruption between the starch and water. Reduced water absorption values obtained in this study could also be linked with the increased syneresis values, since banana flour substitution caused a reduction in the ability of the fermented maize flour to hold water; hence on storage of the gel, water separation (or weeping) occurred in the gel and appeared as a separate phase.

Swelling capacity consistently reduced from 10.80 $\mathrm{g} / \mathrm{ml}$ in $100 \%$ ogi flour to $10.40 \mathrm{~g} / \mathrm{ml}$ on substitution of banana flour up to $50 \%$. Swelling and water absorption capacities are important parameters which ultimately determine sample consistency (that is solid, semi-solid, or liquid) and are dependent on the compositional structure of the sample. Flours with both high water absorption and swelling capacities hold large amounts of water during their preparation into gruels and thus become voluminous with a low energy and nutrient density, while those with low capacities would provide a more nutrient-dense infant formula [22]. Hence, banana flour substitution would provide more nutrient-dense complementary food because of the reduced swelling capacity. Swelling causes changes in hydrodynamic properties of the food thus impacting characteristics such as body, thickening and increase in viscosity to foods. This implies that among the samples, $100 \%$ ogi flour with the highest swelling capacity will produce a thick viscous gruel compared to others. This is probably due to the increase in sugar which reduces swelling of starch granules, hence complementary food made from the flour mixes will have reduced swelling and viscosity and 
higher nutrient density as compared to $100 \%$ ogi flour.

\subsection{Pasting Properties of the Flour Blends}

Pasting properties of the flours varied significantly $(\mathrm{p} \leq$ 0.05 ) as banana substitution level increased (Table 3). Peak viscosity which ranged from 110.00 to $345.30 \mathrm{RVU}$ reduced inconsistently with banana flour substitution. The difference in the peak viscosity may be attributed to different rates of water absorption and swelling of starch granules of the flours during heating which would have been influenced by the increase in sugar content which may result in high solubility whereby the sucrose present ties up water molecules making them unavailable for starch, hence inhibiting normal swelling of starch [18]. The 50:50 flour blend had the highest peak viscosity, hence the highest water binding potential. Breakdown viscosity also reduced, except in the 50:50 flour mix which increased significantly ( $\mathrm{p} \leq 0.05$ ). Breakdown viscosity is regarded as a measure of the degree of disintegration of starch granules or paste stability during heating [22]. The implication of this observation is that the 10:90 flour blend with the lowest breakdown value (11.0 RVU) was more resistant to heat and shear force during heating and that there was less starch granule rupture which could therefore guarantee a more stable cooked paste [23]. Final and setback viscosities reduced in most cases. Since setback viscosity is an indication of the stability of cooked paste against retrogradation and can be used to predict the storage life of a product prepared from the flour [24], the lowest setback observed in 10:90 substitution (38.50 RVU) therefore indicates the lowest rate of starch retrogadation and syneresis tendencies, hence products from this blend will have the longest storage life; whereas the highest value in 30:70 flour (174.59 RVU) the highest retrogradation tendencies and the shortest storage life. Low viscosities observed in the flour blends are nutritionally beneficial in infant formulas. The pasting temperatures which ranged from $73.82^{\circ} \mathrm{C}$ to $81.60^{\circ} \mathrm{C}$ reduced significantly $(\mathrm{p} \leq 0.05)$. The narrow temperature range in the blends indicates that the addition of the Cardaba banana had little effect on the initial pasting temperature of the ogi.

\subsection{Sensory Attributes of Fermented Maize-Cardaba Banana Mixes}

The sensory attributes of ogi and the flour blends as presented in Table 4 were significantly $(\mathrm{p} \leq 0.05)$ different, indicating that samples with varying Cardaba banana substitution levels had higher scores for in most cases than the ogi control. While substitution with Cardaba banana flour significantly improved aroma, colour and mouth feel (smoothness); the taste of 50:50 blend was most preferred, followed by $100 \%$ ogi flour. The highest preference in terms of aroma and taste for 50:50 flour blend shows that addition of banana flour to ogi significantly enhanced its flavour. Similar observation has been reported in a study on breakfast cereal made from maize flour and pawpaw blends [25].

Taste scores were not significantly different for samples containing $10 \%$ and $20 \%$ Cardaba banana; but at $50 \%$ substitution level, the taste significantly improved. This might be due to the high sugar content of Cardaba banana. Among the mixes, flour containing Cardaba banana up to $50 \%$ was rated the highest in terms of colour (4.55), as compared to the ogi control which had the lowest (4.00); however, the $100 \%$ Cardaba banana flour was the most preferred. Values obtained for mouth-feel desirability and smoothness ranged from $6.10-6.50$ and 5.65 - 5.90 respectively. There was significant difference between the sample both in smoothness (texture) and desirability. The sample containing $50 \%$ banana substitution was the most desirable than the ogi control, although

Table 3. Effect of banana substitution on pasting properties (rvu) of fermented maize flour.

\begin{tabular}{|c|c|c|c|c|c|c|c|}
\hline $\begin{array}{l}\text { Level of substitution with } \\
\text { Cardaba banana (\%) }\end{array}$ & Peak viscosity & Trough & Breakdown viscosity & Final viscosity & Setback viscosity & $\begin{array}{l}\text { Peak time } \\
\quad(\min )\end{array}$ & $\begin{array}{l}\text { Pasting Temp } \\
\left({ }^{\circ} \mathrm{C}\right)\end{array}$ \\
\hline 0 & $357.58^{\mathrm{a}}$ & $168.16^{\mathrm{b}}$ & $189.40^{\mathrm{b}}$ & $228.38^{\mathrm{c}}$ & $59.17^{\mathrm{c}}$ & $4.26^{\mathrm{d}}$ & $81.62^{b}$ \\
\hline 10 & $110.0^{\mathrm{f}}$ & $99.0^{\mathrm{f}}$ & $11.0^{\mathrm{g}}$ & $199.1^{\mathrm{e}}$ & $38.50^{\mathrm{f}}$ & $4.20^{\mathrm{e}}$ & $75.20^{\mathrm{d}}$ \\
\hline 20 & $240.12^{\mathrm{d}}$ & $102.17^{\mathrm{e}}$ & $137.08^{\mathrm{d}}$ & $144.13^{\mathrm{g}}$ & $40.41^{\mathrm{e}}$ & $4.26^{\mathrm{e}}$ & $75.20^{\mathrm{d}}$ \\
\hline 30 & $301.54^{\mathrm{c}}$ & $213.0^{\mathrm{a}}$ & $88.54^{\mathrm{e}}$ & $390.63^{\mathrm{a}}$ & $174.58^{\mathrm{a}}$ & $4.80^{\mathrm{b}}$ & $75.20^{\mathrm{d}}$ \\
\hline 40 & $302.56^{\mathrm{c}}$ & $131.66^{\mathrm{c}}$ & $170.9^{c}$ & $177.15^{\mathrm{f}}$ & $43.81^{\mathrm{e}}$ & $4.06^{\mathrm{f}}$ & $73.82^{\mathrm{e}}$ \\
\hline 50 & $345.3^{\mathrm{b}}$ & $18.41^{\mathrm{f}}$ & $326.89^{\mathrm{a}}$ & $230.67^{\mathrm{b}}$ & $48.54^{\mathrm{d}}$ & $4.65^{\mathrm{c}}$ & $79.60^{c}$ \\
\hline 100 & $168.31^{\mathrm{e}}$ & $128.67^{\mathrm{d}}$ & $39.64^{\mathrm{f}}$ & $207.63^{\mathrm{d}}$ & $77.92^{\mathrm{b}}$ & $5.06^{\mathrm{a}}$ & $84.60^{\mathrm{a}}$ \\
\hline
\end{tabular}

Each value is a mean of triplicate determination. Values in the same row with same letters are not significantly different (p<0.05). $0 \%=100 \%$ fermented maize flour, $10 \%=90 \%$ fermented maize flour $+10 \%$ Cardaba banana; $20 \%=80 \%$ fermented maize flour $+20 \%$ Cardaba banana; $30 \%=70 \%$ fermented maize flour $+30 \%$ Cardaba banana; $40 \%=60 \%$ fermented maize flour $+40 \%$ Cardaba banana; $50 \%=50 \%$ fermented maize flour $+50 \%$ Cardaba banana; and $100 \%=$ $100 \%$ Cardaba banana flour. 
Table 4. Effect of banana substitution on sensory properties of fermented maize-extract.

\begin{tabular}{|c|c|c|c|c|c|c|}
\hline $\begin{array}{l}\text { Level of substitution with } \\
\text { Cardaba banana (\%) }\end{array}$ & Aroma & Taste & Colour & $\begin{array}{c}\text { Mouth-feel } \\
\text { (smoothness) }\end{array}$ & $\begin{array}{c}\text { Mouth-feel } \\
\text { (desirability) }\end{array}$ & Overall Acceptability \\
\hline 0 & $5.57^{\mathrm{f}}$ & $6.14^{\mathrm{b}}$ & $4.00^{\mathrm{d}}$ & $5.05^{\mathrm{e}}$ & $6.00^{\mathrm{b}}$ & $6.12^{\mathrm{b}}$ \\
\hline 10 & $5.67^{\mathrm{d}}$ & $6.05^{\mathrm{c}}$ & $4.44^{\mathrm{d}}$ & $5.65^{\mathrm{c}}$ & $6.10^{\mathrm{a}}$ & $6.09^{\mathrm{b}}$ \\
\hline 20 & $5.92^{\mathrm{d}}$ & $6.00^{\mathrm{c}}$ & $4.44^{\mathrm{d}}$ & $5.59^{\mathrm{a}}$ & $5.99^{\mathrm{b}}$ & $5.97^{\mathrm{c}}$ \\
\hline 30 & $6.67^{\mathrm{c}}$ & $5.52^{\mathrm{d}}$ & $4.47^{\mathrm{c}}$ & $5.82^{\mathrm{b}}$ & $5.90^{\mathrm{c}}$ & $5.97^{\mathrm{c}}$ \\
\hline 40 & $6.73^{\mathrm{b}}$ & $6.52^{\mathrm{b}}$ & $4.50^{\mathrm{c}}$ & $5.85^{\mathrm{b}}$ & $5.52^{\mathrm{d}}$ & $5.99^{\mathrm{bc}}$ \\
\hline 50 & $7.70^{\mathrm{a}}$ & $7.00^{\mathrm{a}}$ & $4.55^{\mathrm{b}}$ & $5.90^{\mathrm{a}}$ & $6.50^{\mathrm{c}}$ & $7.70^{\mathrm{a}}$ \\
\hline 100 & $7.02^{\mathrm{a}}$ & $7.00^{\mathrm{a}}$ & $5.00^{\mathrm{a}}$ & $4.05^{\mathrm{f}}$ & $5.40^{\mathrm{e}}$ & $5.00^{\mathrm{d}}$ \\
\hline
\end{tabular}

Each value is a mean of triplicate determination. Values in the same row with same letters are not significantly different $(\mathrm{p}<0.05) .0 \%=100 \%$ fermented maize flour, $10 \%=90 \%$ fermented maize flour $+10 \%$ Cardaba banana; $20 \%=80 \%$ fermented maize flour $+20 \%$ Cardaba banana; $30 \%=70 \%$ fermented maize flour $+30 \%$ Cardaba banana; $40 \%=60 \%$ fermented maize flour $+40 \%$ Cardaba banana; $50 \%=50 \%$ fermented maize flour $+50 \%$ Cardaba banana; and $100 \%=$ $100 \%$ Cardaba banana flour.

the difference was not significant. Scores for overall acceptability showed that the 50:50 ogi-banana blend was the most preferred. Generally, the 50:50 ogi-banana flour blend was the most preferred in terms of aroma, mouth feel, taste and overall acceptability and hence the most accepted.

\section{Conclusion}

The results of the study showed that maize-banana flour mixes had lower amounts of protein, fat and moisture. The lower fat and moisture content are advantageous because they guarantee storability of the flours. Although the incorporation of banana flour to ogi caused significant reduction in its protein content, micronutrients content, functional and pasting properties and sensory attributes were significantly improved. There is, however, the need to enrich the protein content with the use of other plant or animal sources.

\section{REFERENCES}

[1] E. O. I. Banigo and H. G. Muller, "Manufacture of Ogi (a Nigerian Fermented Porridge): Comparative Evaluation of Corn, Sorghum and Millet," Canadian Institute of Food Science and Technology Journal, Vol. 5, No. 4, 1972, pp. 217-221. doi:10.1016/S0315-5463(72)74132-2

[2] T. O. Osungbaro, "Physical and Nutritive Properties of Fermented Cereal Foods," African Journal of Food Science, Vol. 3, No. 2, 2009, pp. 23-27.

[3] U. Okezie, C. T. Akanbi, E. T. Otunola and I. A. Adeyemi, "Effect of Addition of Ripe Bananas on Some Physicochemical Properties of Maize Extract," International Journal of Food Sciences \& Nutrition, Vol. 54, No. 6, 2003, pp. 437-445. doi:10.1080/09637480220138106

[4] J. A. Adejuyitan, A. O. Abioye, E. T. Otunola and Y. N. Oyewole, "An Evaluation of Some Properties of Baobab Fruit Powder and Ogi Mixes," Transnational Journal of Science and Technology, Vol. 2, No. 7, 2012, pp. 99-102.
[5] I. A. Adeyemi and E. O. Soluade, "Development and Quality Evaluation of Pawpaw-Ogi," Plant Foods for Human Nutrition, Vol. 44, No. 3, 1993, pp. 213-220. doi:10.1007/BF01088315

[6] H. N. Ayo-Omogie, I. A. Adeyemi and E. T. Otunola, "Effect of Ripening on Some Physicochemical Properties of Cooking Banana (Musa ABB Cardaba) Pulp and Flour," International Journal of Food Science \& Technology, Vol. 45, No. 12, 2010, pp. 2605-2611. doi:10.1111/j.1365-2621.2010.02432.x

[7] AOAC, "Official Methods of Analysis," 15th Edition, Association of Official Analytical Chemists, Washington DC, 1990.

[8] L. R. Beuchat, "Functional and Electrophoretic Characteristics of Succinylated Peanut Flour," Journal of Agriculture and Food Chemistry, Vol. 25, No. 2, 1977, pp. 258-261. doi:10.1021/jf60210a044

[9] K. Narayana and M. S. Narasinga Rao, "Effect of Partial Proteolysis on the Functional Properties of Winged Bean Phosphocarpus tetragonolobus Flour," Journal of Food Science, Vol. 49, No. 3, 1984, pp. 944-947. doi:10.1111/j.1365-2621.1984.tb13247.x

[10] J. A. Delcour, J. Vanstelandt, M. C. Hythier and J. Abecassis, "Fractionation and Reconstitution Experiments Provide Insight into the Role of Starch Gelatinisation and Pasting Properties in Pasta Quality," Journal of Agricultural and Food Chemistry, Vol. 48, No. 9, 2000, pp. 377-378.

[11] I. A. Adeyemi and O. Beckley, "Effect of Period of Maize Fermentation and Souring on Chemical Properties and Amylograph Pasting Viscosity of Ogi," Journal of Cereal Science, Vol. 4, No. 4, 1986, pp. 353-360. doi:10.1016/S0733-5210(86)80039-X

[12] N. N. Potter and S. Hotchkiss, "Food Science," 5th Edition, Chapman and Hall, Inc., New York, 1995.

[13] W. Forsyth, "Bananas and Plantains," In: S. Nagy and P. E. Shaw, Eds., Tropical and Subtropical Fruits, AVI Publishing Inc., Westport, 1980, pp. 24-33.

[14] FAO, "Roots, Tubers, Plantains and Bananas in Human nutrition," FAO, Rome, 1989. 
[15] G. Reed, "Enzymes in Food Processing," 2nd Edition, Academic Press, New York, 1975.

[16] Y. Kurrimoto and D. R. Shelton, "The Effect of Flour Particle Size on Baking Quality and Other Flour Attributes," Cereal Foods World, Vol. 33, No. 4, 1988, pp. 429-433.

[17] M. L. Bean and E. M. Osman, "Behaviour of Starch during Food Preparation II: Effect of Different Sugars on the Viscosity and Gel Strength of Starch Pastes," Food Resource, Vol. 24, No. 6, 1959, pp. 65-67.

[18] M. Glicksman, "Gum Technology in the Food Industry," Academic Press, New York, 1969.

[19] N. G. Malleshi and H. S. R. Desikachar, "Development of Weaning Food with High Caloric Density and Low Paste Viscosity Using Traditional Technologies," Food and Nutrition Bulletin, Vol. 2, No. 4, 1982, pp. 18-21.

[20] F. M. A. Abass, R. Saifullah and M. E. Azhar, "Assessment of Physical Properties of Ripe Banana Flour Prepared from Two Varieties: Cavedish and Dream Bananas," International Food Research Journal, Vol. 16, 2009, pp. 183-189.

[21] I. A. Onimawo and K. M. Egbekun, "Comprehensive
Food Science and Nutrition," Revised Edition, Ambik Publishers, Benin City, 1998.

[22] H. N. Dengate, "Swelling, Pasting, and Gelling of Wheat Starch," In: Y. Pomeranz, Ed., Advances in Cereal Science and Technology, American Association for Clinical Chemistry (AACC), Washington DC, 1984.

[23] I. A. Farhat, T. Oguntona and J. R. Neale, "Characterization of Starches from West African Yams," Journal of Science of Food and Agriculture, Vol. 79, No. 15, 1999, pp. 2105-2111.

doi:10.1002/(SICI)1097-0010(199912)79:15<2105::AIDJSFA510>3.0.CO;2-R

[24] I. S. M. Zaidul, H. Yamauchi, S. Takiyawa, C. MatsuuraEndo, T. Suzuki and T. Noda, "Correlation between the Compositional and Pasting Properties of Various Potato Starches," Food Chemistry, Vol. 105, No. 1, 2007, pp. 164-172. doi:10.1016/j.foodchem.2007.03.061

[25] N. J. Enwere and I. G. Ntuen, "Effect of Ripe Banana, Pineapple and Pawpaw Pulp Fruits of Weaning Food Formulation," International Journal of Food Science and Nutrition, Vol. 40, 1990, pp. 439-451. 